\title{
Clinical functional evaluation of female's pelvic floor: integrative review
}

\author{
Avaliação clínico-funcional do assoalho pélvico \\ feminino: revisão integrativa
}

\section{Ana Carolina Nociti Lopes Fernandes ${ }^{[a]}$, Bianca Manzan Reis ${ }^{[b]}$, Lislei Jorge Patrizzi ${ }^{[c]}$, Maria Cristina Cortez Carneiro Meirelles ${ }^{[\mathrm{c}]^{*}}$}

[a] Universidade de São Paulo (USP), Ribeirão Preto, SP, Brazil

[b] Universidade Federal de São Carlos (UFSCar), São Carlos, SP, Brazil

[c] Universidade Federal do Triângulo Mineiro (UFTM), Uberaba, MG, Brazil

\section{Abstract}

Introduction: The effectiveness of pelvic floor muscle training (PFMT) depends on the correct prescription of intensity, repetition and endurance of muscle contractions, which are provided by an adequate assessment of pelvic floor muscle. Objective: Verify the techniques, resources and strategies used for clinical functional evaluation of female pelvic floor (PF) described in literature. Methods: It's an integrative review of published studies and books from 2010 until December 2015. Relevant articles with complete description of PF evaluation were found through the use of Scielo, LILACS, PubMed and Medline databases. Results: 34 articles that fulfilled all the criteria were selected. Conclusion: The most used techniques, resources and strategies were: anamnesis, physical examination, measurement of pelvic floor muscle activity using Modified Oxford Scale or perineometry, and use of questionnaires to analyze patient's perspective of their own symptoms. Thus, we could use the parameters obtained in the evaluation to plan an ideal PFMT for each patient, so the physiotherapist would have a good database to analyze the evolution and define the end of therapy.

Keywords: Pelvic Floor. Women's Health. Physical Therapy Specialty.

ACNLF: Master's student, e-mail: carol_nociti@hotmail.com BMR: Master's student, e-mail: reis.bianca@yahoo.com.br LJP: PhD, e-mail: lispatrizzi@gmail.com

MCCCM: PhD, e-mail: marmeirelles@gmail.com 


\section{Resumo}

Introdução: A eficácia do treinamento da musculatura do assoalho pélvico (TMAP) depende da correta prescrição dos exercícios em relação à intensidade, repetição e sustentação das contrações dessa musculatura, dados que são fornecidos quando realizada uma avaliação adequada. Objetivo: Verificar as técnicas, os recursos e as estratégias utilizadas para a avaliação clínico-funcional do assoalho pélvico (AP) feminino descritos na literatura. Métodos: Revisão integrativa de trabalhos publicados a partir de 2010 até dezembro de 2015, disponíveis em livros da área e nas bases de dados Scielo, LILACS, PubMed e MedLine sendo selecionados apenas os trabalhos que apresentaram a avaliação na íntegra. Resultados: Foram selecionados 34 artigos que preencheram todos os critérios de inclusão. Conclusão: Verificou-se que as técnicas, recursos e estratégias mais utilizadas foram: anamnese, exame físico, mensuração da atividade dos músculos do assoalho pélvico por meio da Escala de Oxford Modificada e/ou perineometria, além do uso de questionários para análise da perspectiva do paciente sobre seus sintomas. Desta forma, poderíamos utilizar os parâmetros obtidos na avaliação para traçar o TMAP ideal para cada paciente e o fisioterapeuta teria uma boa base de dados para analisar a evolução e definir alta do paciente.

Palavras-chave: Diafragma da Pelve. Saúde da Mulher. Fisioterapia.

\section{Introduction}

The pelvic floor (PF) is a muscle-fascial structure that inferiorly limits the pelvic cavity and is composed of the pelvic and urogenital diaphragms [1]. They function as a single functional unit, promoting support for the pelvic organs and maintaining the urinary and anal continence with their contraction in the anterior-superior direction, with participation in sexual function $[1,2]$.

The dysfunction of this musculature can affect both quality of life and sexuality and is a reflex of basal tonus and the ability of contracting and / or relaxing voluntarily [1 - 4]. Since the 1990s, it has been demonstrated in the literature that the weakness of the pelvic floor muscles (PFM) in women generates an imbalance in the region, causing dysfunctions such as urinary (UI) and anal incontinence (AI), pelvic organs prolapse (POP) and sexual dysfunctions (SD) [1, 2, 4 - 6].

The treatment recognized as golden pattern by the International Continence Society (ICS) for these dysfunctions is pelvic floor muscle training (PFMT) [7 - 9]. It aims to increase the sphincteric function around the urethra, the support of the pelvic organs, local blood circulation, re-education and hypertrophy of PFM, as well as to contribute to the improvement of sexual activity [10]. The PFMT may be associated with other resources such as surgeries and medications, biofeedback and vaginal cones, as well as changes in habits [7 - 9].

The effectiveness of the PFMT depends on the correct prescription of the exercises in relation to the intensity, repetition and sustentation of PFM contractions. For that matter, the responsible physiotherapist must be able to properly evaluate these items to elaborate their procedures $[11,12]$.

This study aims to verify the techniques, resources and strategies used for clinical functional evaluation of female PF described in the literature.

\section{Methods}

This is an integrative review study performed according to the phases presented by Whittemore and Knafl [13] and based on the guiding question "How to perform the clinical functional evaluation of the female PF?".

The research and selection of the material published from 2010 to December 2015 was carried out by two independent researchers. The databases Scielo, LILACS, PubMed and MedLine were used, associating the descriptors Pelvic Floor, Perineum, Evaluation, Physical Therapy and Women, as well as manual research in area books. The papers were selected by reading the abstract, and the procedures related to the clinical functional evaluation of the female FP should be present in 
it. Papers assessing women and men, which tested or validated methods / instruments of evaluation and used ultrasonography or magnetic resonance imaging were excluded.

Researchers independently extracted the following information: identification (author / year, magazine in which the paper has been published and its Qualis classification) type of study, level of evidence [13] sample characteristics, objective, additional questionnaires, scale, equipment and muscular conditions / maneuvers of the PF clinical functional evaluation. After this step, the congruence of the information obtained was checked and, in case of disagreement to the selection of a specific paper, the opinion of a third researcher was requested. The analysis of the worksheet sought to answer the guiding question of the present work.

\section{Results}

The selections resulted in a heterogeneous final sample of 34 articles composed of seven $(20.6 \%)$ with level of evidence two, 11 (32.5\%) level three, $14(41.17 \%)$ level four and two (5.9\%) level six. Only one $(2.9 \%)$ article was published in the journal with Qualis A1, two (5.8\%) in A2, 14 (41.17\%) in $\mathrm{B} 1,12(35.3 \%)$ in $\mathrm{B} 2$, three $(8.7 \%)$ in $\mathrm{B} 3$ and two $(5.8 \%)$ in $\mathrm{B} 4$. The sample was also characterized by 17 studies (50\%) that evaluated the PFM to verify the effectiveness of a procedure, while $15(44.12 \%)$ described the condition of the PFM, and two (5.8\%) that were revisions of the literature about the topic.

Table 1 presents the description of the procedures used in each article for the clinical functional evaluation of the female FP.

Table 1 - Clinical functional evaluation of PF present in articles

\begin{tabular}{|c|c|c|c|}
\hline \multirow{2}{*}{$\begin{array}{l}\text { Identification } \\
\text { Author / year }\end{array}$} & \multicolumn{3}{|c|}{ Evaluation } \\
\hline & Scale & Equipment & Muscular Conditions/ Maneuvers \\
\hline Alves et al., 2011 & - & Perineometry & $\begin{array}{l}3 \text { maximum voluntary contractions (MVC) sustained } \\
\text { for } 4 \text { seconds (") associated with increased } \\
\text { intra-abdominal pressure maneuvers }\end{array}$ \\
\hline Araujo et al., 2015 & Ortiz & Perineometry & Basal Tonus (BT) and MVC sustained for at least 3" \\
\hline Assis et al., 2012 & Modified Oxford (MOS) & Perineometry & $3 \mathrm{MVC}$ \\
\hline Beuttenmuller et al., 2011 & MOS & Perineometry & MVC and sustained contractions (SC) up to $6 "$ \\
\hline Caroci et al., 2014 & MOS & Perineometry & 3 MVC sustained for $5 "$ \\
\hline Castro et al., 2012 & MOS & Perineometry & 3 MVC being annotated the endurance \\
\hline Correia et al., 2013 & MOS & Perineometry & 3 MVC sustained for $3 "$ \\
\hline Dias et al., 2011 & MOS & _ & _ \\
\hline Ferederice et al., 2011 & MOS & Electromyography (EMG) & BT for 1 minute ('), 3 MVC and 3 SC for $10 "$ \\
\hline Fitz et al., 2012 & MOS / PERFECT & - & - \\
\hline Fitz et al., 2012 & MOS / PERFECT & _ & _ \\
\hline Gameiro et al., 2011 & Amaro & Perineometry & $3 \mathrm{SC}$ for as long as possible \\
\hline Gameiro et al., 2012 & - & Perineometry & The MVC pressure and mean, and endurance \\
\hline Gouveia et al., 2012 & $\begin{array}{l}\text { Ortiz, tefim-perineal e } \\
\text { MOS / PERFECT }\end{array}$ & $\begin{array}{l}\text { EMG; Perineometry and } \\
\text { Vaginal Cones }\end{array}$ & $\begin{array}{l}\text { BT, MVC and SC were considered during assessment } \\
\text { using EMG; there was no specification on the use of } \\
\text { perineometry; and for vaginal cones was considered } \\
\text { the highest sustained weight }\end{array}$ \\
\hline Haddad et al., 2011 & Ortiz & - & - \\
\hline Knorst et al., 2012 & Ortiz & Perineometry & $3 \mathrm{MVC}$ \\
\hline Knorst et al., 2013 & Ortiz & - & - \\
\hline Knorst et al., 2013 & Ortiz & Perineometry & 3 contractions \\
\hline Kruger et al., 2011 & Ortiz & - & - \\
\hline Langoni et al., 2014 & Ortiz & Perineometry & $3 \mathrm{MVC}$ \\
\hline Loving et al., 2014 & MOS & EMG and palpometer & $\begin{array}{l}\text { BT for 1', contraction and relaxation capacity; } \\
\text { And pressure in which was reported an onset of pain }\end{array}$ \\
\hline
\end{tabular}

(To be continued) 
Table $\mathbf{1}$ - Clinical functional evaluation of PF present in articles

\begin{tabular}{|c|c|c|c|}
\hline \multirow{2}{*}{$\begin{array}{l}\text { Identification } \\
\text { Author / year }\end{array}$} & \multicolumn{3}{|c|}{ Evaluation } \\
\hline & Scale & Equipment & Muscular Conditions/ Maneuvers \\
\hline Lúcio et al., 2011 & MOS /PERFECT & - & - \\
\hline Lúcio et al., 2014 & MOS / PERFECT & _- & _ \\
\hline Marques et al., 2012 & MOS & EMG & $3 \mathrm{MVC}$ \\
\hline Martinez et al., 2014 & Ortiz & Perineometry & 3 MVC sustained \\
\hline Massuia et al., 2010 & - & Perineometry & $\begin{array}{l}3 \text { isolated contractions associated with evaluation of } \\
\text { the respiratory musculature }\end{array}$ \\
\hline Resende et al., 2011 & - & EMG & $\begin{array}{l}\text { SC for } 3 \text { ", } 10 \text { ", } 30 \text { " and } 60 \text { "; BT for } 1 \text { ' followed by } 5 \\
\text { MVC and } 2 \text { SC for } 10 \text { " and } 20 \text { "; moderate and discreet } \\
\text { MVC; } 3 \text { MVC, } 10 \text { " of contraction and } 10 \text { " of resting }\end{array}$ \\
\hline Resende et al., 2012 & MOS & EMG & BT for 10 " and 2 MVC sustained for $5 "$ \\
\hline Riesco et al., 2014 & _ & Perineometry & 3 MVC sustained for $5 "$ \\
\hline Sousa et al., 2011 & Ortiz & Perineometry & 3 MVC sustained as long as possible \\
\hline Valeton; Amaral, 2011 & - & Perineometry & $3 \mathrm{MVC}$ \\
\hline Virtuoso et al., 2010 & Ortiz & - & - \\
\hline Virtuoso et al., 2011 & MOS/ PERFECT & Perineometry & 5 fast e 5 SC \\
\hline Wang et al., 2013 & - & EMG & $\begin{array}{l}3 \text { MVC sustained for as long as possible, } 3 \text { series of } \\
\text { the highest amount of fast MVC in } 6 \text { " }\end{array}$ \\
\hline
\end{tabular}

In addition to the presented resources, 14 articles used eight different questionnaires. The King's Health Questionnaire (KHQ) was used in six studies $(42.86 \%)$, the International Consultation on Incontinence Questionnaire (ICIQ-SF) in four studies (28.57\%), the International Physical Activity Questionnaire (IPAQ) and Female Sexual Function Index (FSFI) in two papers each (14.28\%). The Overactive Bladder Questionnaire (OAB-q), Short Form-36 (SF-36), International Consultation on Incontinence Questionnaire (ICIQ-UI) and International Consultation on Incontinence Questionnaire Overactive Bladder (ICIQ-OAB) were used in one article each (7.14\%). Some articles used more than one questionnaire.

\section{Discussion}

The proven efficacy, easy application, low cost and absence of side effects make PFMT widely used as a treatment resource $[8,9,12]$. However, if used without considering the specificities of each patient, its efficacy is reduced $[11,12]$. In order for PFMT not to be trivialized, it is important that the physiotherapist is able to perform a PFM assessment, even with reduced availability of equipment. With this in mind, we tried to bring to this review what is described in the literature of the clinical functional evaluation of female PF to guide physiotherapists through choosing the structure of their evaluation without loss of scientific basis.

Due to the great amount of published works in the area of urogynecological physiotherapy, we opted for an integrative review. This methodology is broad, developed in specific steps that allow the inclusion of all methodological designs, providing the synthesis of knowledge and facilitating applicability in clinical practice $[13,14]$. The integrative review also seeks to aggregate the largest amount of information available, classifying the level of evidence of the works and critically analyzing its content, thus justifying the absence of exclusion criterion regarding the level of evidence of the selected papers and the Qualis of the journal in which it was published [14]. It is also justified by the intention to bring PF functional assessment techniques that can be used in clinical practice at any level of attention to health and socioeconomic level of the physiotherapist, always aiming at EvidenceBased Practice.

The exclusion of studies evaluating PFM using ultrasound and magnetic resonance imaging are justified by their still experimental use and the difficulty of being accessed in the physiotherapist's clinical practice [15]. 
More than $70 \%$ of the studies found in the present review were classified as belonging to levels of evidence 3 and 4, i.e. almost experimental and non-experimental studies, respectively. This finding may be justified by the difficulty of adapting a methodology to the characteristics of an experimental study [16]. The difficulty of carrying out studies with higher levels of evidence may also justify the publication of more than $75 \%$ of papers in scientific journals with Qualis B1 and B2.

Of the studies analyzed, $50 \%$ used the PF evaluation to analyze a certain procedure and/or PFMT results, and no studies with the objective of presenting protocols for evaluation were found in this search.

Awareness of the function and location of PFM is closely related to the efficacy of PFMT, which depends on a correct prior assessment [11]. Despite the knowledge of this fact, only six studies described the orientation of the anatomy and functionality of the PFM before the evaluation in their methodology [4, 16 - 21].

An initial physical examination with inspection of the perineal region is recommended, as well as the assessment of tone and muscle mass, seeking neurological or anatomical changes and discarting infections and the presence of POP [22]. This initial examination was reported in only three studies [15, 21,23]. This finding is extremely worrysome as, since the initial examination is not performed, the physiotherapist will not have parameters to establish proper treatment and prognosis for the patient, characterizing a poor-quality care.

According to IUGA, evaluation using digital palpation should be used to verify the static and dynamic strength, endurance, repetitions, relaxation capacity and PFM coordination [22]. The most used scale for recording digital palpation findings was Modified Oxford Scale (MOS), cited by 16 articles [15, 17, 18, 20, $23-34]$, followed by Ortiz in 11 articles [4, 15, 20, 35 - 42], Amaro [43] and Tefim-perineal [15] for one article each. The digital palpation was not performed in seven articles and the musclulature was evaluated by electromyography $[21,44]$ or perineometry [ 45 - 49]. Amongthoseusing the MOS, sixarticlescomplemented their evaluation using the PERFECT method even if adapted [15, 18, 23, 27, 29, 33].

The MOS classifies the PFM contraction from 0 to 5 , according to the capacity of this musculature contract anterosuperiorly overcoming resistance, without considering the exact endurance [26]. PERFECT is a method proposed by Bo and Larsen that complements the MOS with endurance verification, number of sustained and fast contractions and the relaxation capacity [15]. The Ortiz scale classifies PFM contraction from 0 to 4 considering the capacity of them to overcome a resistance as well as the endurance [15] while the Amaro's classifies from 0 to 3 the contraction, observing its intensity and capacity of sustentation [43] and Tefim-perineal considers the endurance and the repetitions through resistance [15].

Although no reference has been found comparing the MOS and Ortiz scales, it may be noted that the use of both is related to the examiner's experience, the first one subdivides the correct contraction into different palpable sensations while the second limits the subjective perception of the contraction's intensity. The description of the palpable sensations involved in the classification of PFM contraction according to the MOS is a facilitator for its use, despite the fact that the Ortiz scale considers the endurance. This issue could be easily solved by using the MOS associated with the PERFECT method which, as can be observed, is the digital palpation assessment that is closest to what is recommended by IUGA and ICS [22].

However, it has been observed that only the knowledge of the PERFECT method is insufficient to guarantee its effective use, since two of the studies found reported its use with adaptations, excluding important steps such as endurance, repetitions and relaxation capacity $[18,27]$. Therefore, it is relevant to emphasize the importance of the awareness of clinical professionals about this fact, since, in addition to being recommended by IUGA and ICS, the information obtained during the evaluation favors the prescription of a PFMT considering the specificities of the patient.

Most of the selected articles, 19, used perineometry to complement or even as a single method of PFM evaluation [4, 15, 24, 29 - 32, 35, 36, $38,39,41,43,45-49]$, seven used electromyography $[15,20,21,26,28,34,44]$, one palpometer [28], vaginal cones [15] and nine did not use an additional method, and the results were obtained through digital palpation [17 - 19, 23, 27, 28, 33, 37, 42].

The perineometer was the first device developed to objectively evaluate and quantifies the PFM contraction by the measurement of vaginal 
pressure $[1,15,41]$. It is a simple equipment with quick application, little invasive and able to evaluate the capacity of contraction and endurance [50, 51]. Although it is the resource used in more than 50\% of the studies of this sample, its use has limitations due to the difficulty to determine the correct positioning of the probe, the capture of the increase of intra-abdominal and / or intra-vaginal pressure by incoordination when performing PFM contraction and / or simultaneous contraction of other muscle groups [1].

Electromyography is a technique that detects the electrical potentials generated during muscle contraction through surface or needle electrodes. Although needle electrodes are more suitable for the evaluation of small muscle groups, such as PFM, the surface is more commonly used and is attached to a vaginal or anal probe $[1,44]$. The difficulty in using the correct electrode, the non-linear response of the musculature to the requested maximal voluntary contraction, the existence of crosstalk and the need for caution in the analysis of the collected data make the electromyography more used in research than in clinical practice [1].

As shown in Table 1, there is no standardization of contractions assessement, which makes it difficult to compare the results obtained by different studies, both for characterization of the musculature and for verifying the effectiveness and compare results of different interventions. In addition, the specificity of each patient in relation to their capacity of resistance and repetitions is not considered. Emphasis should be given on the study of Wang et al. [21], which evaluated three contractions sustained by as long as the patient was able to and three series with the highest number of fast VMC in 6 seconds. It was the only selected study that approached an evaluation considering the conditions of each patient.

Other devices may be used in the evaluation of PFM, but are rarely reported in the literature $[1,15,28]$, two of which are vaginal cones and palpometer. The vaginal cones are devices of equal sizes and different weights that are introduced into the vaginal canal and must be sustained by PFM activation and the force of this muscle is classified according to the weight of the cone that was able to sustain for one minute $[1,15]$. The palpometer evaluates the mechanical sensitivity of the vaginal wall through the report of pain by increasing the pressure [28].
When the real need for the use of the most mentioned equipment in our sample was analyzed critically in the clinical practice of the Brazilian physiotherapist, it can be observed that these are equipment of considerable high acquisition value and with a positive correlation with the MOS [50 - 52]. Therefore, its use may be considered dispensable and replaced by digital palpation with the use of the MOS supplemented by the PERFECT method.

The fifth international incontinence guideline states that the patient's perspective on his or her symptoms is the most appropriate method of reporting their progress and can be analyzed by general or specific quality of life questionnaires for PFM dysfunctions both in clinical practice and in research [53]. In the selected studies, the most used questionnaires were KHQ and ICIQ-SF, both validated and adapted to the Brazilian culture. However, the first one evaluates the presence of UI symptoms and their relative impact on several aspects of quality of life, while the second evaluates the impact of UI on quality of life and qualify urinary loss $[54,55]$. It is not surprising that the two questionnaires correlate in a moderate way, after all they do not evaluate the same concepts, but rather, concepts that are related [55].

We consider important to apply questionnaires related to patient's main complaint, if this refers to the symptoms of UI, the use of KHQ is the best option, in case of SD the use of FSFI or others that already present cultural validation and adaptation in Brazil is more recommended.

\section{Conclusion}

The resources and strategies used for clinical functional evaluation of the female PF described in the literature are: the awareness of PFM location and function; the initial physical examination; the assessment of the capacity of PFM contraction by digital palpation with the use of MOS complemented or not by the PERFECT method, Ortiz, Amaro or Telfim-perineal; quantification of aspects of muscle contraction through perineometry, electromyography, vaginal cones and palpometer; and the analysis of the patient's perspective on their symptoms by the KHQ ICIQ-SF, FSFI, OAB-q, ICIQ-OAB and SF-36 questionnaires.

We consider that MOS complemented by the PERFECT method is the evaluation mode that considers the most aspects of the PFM contraction, 
therefore, it also provides more parameters for an individualized training. The non-use in clinical practice of equipment that quantifies aspects of muscle contraction does not affect the results expected by PFMT due to the correlation between perineometry, electromyography and MOS.

We suggest that additional studies should be performed with the aim of improving and standardizing the clinical functional evaluation of the female PF. Thus, the parameters obtained can be used to develop the ideal PFMT for each patient and guide the physiotherapist in the analysis of the evolution and definition of when to finish it, favoring evidence-based practice.

\section{References}

1. Bo K, Sherburn M. Evaluation of Female Pelvic-Floor Muscle Function and Strength. Phys Ther. 2005; 85(3):269-82.

2. Yiou R, Costa P, Haab F, Delmas V. Anatomie fonctionnelle du plancher pelvien. Prog urol. 2009; 19(13):916-25.

3. Fitz FFF, Costa TF, Yamamoto DM, Resende APM, Stupp L, Sartori MGF, et al. Impacto do treinamento dos músculos do assoalho pélvico na qualidade de vida em mulheres com incontinência urinária. AMB Rev Assoc Med Bras. 2012;58(2):155-9.

4. Martinez CS, Ferreira FV, Castro AAM, Gomide LB. Women with greater pelvic floor muscle strength have better sexual function. Acta Obstet Gynecol Scand. 2014;93(5):497-502.

5. Bitti GT, Argiolas GM, Ballicu N, Caddeo E, Cecconi M, Demurtas G, Matta G, Peltz MT, Secci S, Siotto P. Pelvic Floor Failure: MR Imaging Evaluation of Anatomic and Functional Abnormalities. Radiographics. 2014;34(2): 429-48.

6. Eickmeyer SM. Anatomy and Physiology of the Pelvic Floor. Phys Med Rehabil Clin N Am. 2017;28(3):455-60.

7. Abrams P, Andersson KE, Birder L, Brubaker L, Cardozo L, Chapple C, et al. Fourth international consultation on incontinence recommendations of the international scientific committee: evaluation and treatment of urinary incontinence, pelvic organ prolapse, and fecal incontinence. Neurourol Urodyn. 2010; 29(1):213-40.
8. Hay-Smith J, Bo K, Berghmans B, Hendriks E, de Bie $\mathrm{R}$, van Waalwijk van Doorn E. Pelvic floor muscle training for urinary incontinence in women. Cochrane Database Syst Rev. 2008;(3):CD001407.

9. Ayeleke RO, Hay-Smith EJC, Omar MI. Pelvic floor muscle training added to another active treatment versus the same active treatment alone for urinary incontinence in women. Cochrane Database Syst Rev. 2015;(11):CD010551.

10. Burti JS, Hacad CR, Zambon JP, Polessi EA, Almeida FG. Is there any difference in pelvic floor muscles performance between continent and incontinent women? Neurourol Urodyn. 2014;34(6):544-8.

11. Glisoi SFN, Girelli P. Importância da fisioterapia na conscientização e aprendizagem da contração da musculatura do assoalho pélvico em mulheres com incontinência. Rev Bras Clin Med. 2011;9(6):408-13.

12. Silva Filho AL, Fonseca AMRM, Camillato ES, Cangussu RO. Análise dos recursos para reabilitação da musculatura do assoalho pélvico em mulheres com prolapso e incontinência urinária. Fisioter. pesqui. 2013;20(1):90-6.

13. Whittemore $\mathrm{R}$, Knafl $\mathrm{K}$. The integrative review: updated methodology. J Adv Nurs. 2005;52(5):546-53.

14. Souza MT, Silva MD, Carvalho R. Revisão integrativa: o que é e como fazer. Einstein. 2010;8(1):102-6.

15. Gouveia PF, Ambrogini CC, Haiddar MA, Silva I. Métodos de avaliação do assoalho pélvico. RBM Rev Bras Med. 2012;70(6): 232-8.

16. Malavolta EA, Demange $M K$, Gobbi RG, Imamura $M$, Fregni F. Ensaios clínicos controlados e randomizados na ortopedia: dificuldades e limitações. Rev Bras Ortop. 2011;46(4): 452-59.

17. Dias LAR, Driusso P, Aita DLCC, Quintana SM, Bø K, Ferreira CHJ. Effect of pelvic floor muscle training on labour and newborn outcomes: a randomized controlled trial. Braz J Phys Ther. 2011;15(6): 487-93.

18. Fitz FF, Costa TF, Yamamoto DM, Resende APM, Stüpp L, Sartori MGF, et al. Impacto do treinamento dos músculos do assoalho pélvico na qualidade de vida em mulheres com incontinência urinária. AMB Rev Assoc Med Bras. 2012;58(2):155-9. 
19. Haddad JM, Ribeiro RM, Bernardo WM, Abrão MS, Baracat EC. Vaginal cone use in passive and active phases in patients with stress urinary incontinence. Clinics. 2011;66(5): 785-91.

20. Resende APM, Petricelli CD, Bernardes BT, Alexandre SM, Nakamura MU, Zanetti MRD. Electromyographic evaluation of pelvic floor muscles in pregnant and nonpregnant women. Int Urogynecol J. 2012;23(8):1041-5.

21. Wang L, Chen X, Li X, Gong Y, Li H, Tong X. The improvement of pelvic floor muscle function in POP patients after the Prolift procedure: results from surface electromyography. Int Urogynecol J. 2013;24(10):1703-8.

22. Haylen BT, Ridder D, Freeman RM, Swift SE, Berghmans B, Lee J, et al. An International Urogynecological Association (IUGA)/ International Continence Society (ICS) joint report on the terminology for female pelvic floor dysfunction. Neurourol Urodyn. 2010;29(1):4-20.

23. Lúcio AC, D’Ancona CA, Lopes MH, Perissinotto MC, Damasceno BP. The effect of pelvic floor muscle training alone or in combination with electrostimulation in the treatment of sexual dysfunction in women with multiple sclerosis. Mult Scler. 2014;20(13):1761-8.

24. Assis TR, Sá ACAM, Amara WN, Batista EM, Formiga CKMR, Conde DM. Efeito de um programa de exercícios para o fortalecimento dos músculos do assoalho pélvico de multíparas. Rev Bras Ginecol Obstet. 2013;35(1):10-5.

25. Castro LA, Sobottka W, Baretta G, Freitas ACT. Efeitos da cirurgia bariátrica na função do assoalho pélvico. ABCD Arq Bras Cir Dig. 2012;25:263-8.

26. 26. Ferederice CP, Amaral E, Ferreira NO. Sintomas urinários e função muscular do assoalho pélvico após o parto. Rev Bras Ginecol Obstet. 2011;33(4):188-95.

27. Fitz FF, Resende APM, Stüpp L, Costa TF, Sartori MGF, Girão MJBC, et al. Efeito da adição do biofeedback ao treinamento dos músculos do assoalho pélvico para tratamento da incontinência urinária de esforço. Rev Bras Ginecol Obstet. 2012;34(11):505-10.

28. Loving S, Thomsen T, Jaszczak P, Nordling J. Pelvic floor muscle dysfunctions are prevalent in female chronic pelvic pain: A cross-sectional populationbased study. Eur J Painz. 2014;18(9):1259-70.
29. Virtuoso JF, Mazo GZ, Menezes EC. Incontinência urinária e função muscular perineal em idosas praticantes e não-praticantes de atividade física regular. Braz Phys Ther. 2011;15: 310-7.

30. Beuttenmüller L, Cader SA, Macena RHM, Araujo NS, Nunes EFC, Dantas EHM. Contração muscular do assoalho pélvico de mulheres com incontinência urinária de esforço submetidas a exercícios e eletroterapia: um estudo randomizado. Fisioter Pesqui. 2011;18(3):210-6.

31. Caroci AS, Riesco MLG, Rocha BMC, Ventura LJ, Oliveira SG. Avaliação da força muscular perineal no primeiro trimestre da gestação. Rev Latinoam Enferm. 2014;22(6):893-901.

32. Correia GN, Ferreira CHJ, Aveiro MC, Pereira VS, Driusso P. Pelvic floor muscle training decreases hip adductors isometric peak torque in incontinent women: an exploratory study. Fisioter Mov. 2013;26(1):183-90.

33. Lúcio AC, Perissinoto MC, Natalin RA, Prudente A, Damasceno BP, D’ancona CAL. A comparative study of pelvic floor muscle training in women with multiple sclerosis: its impact on lower urinary tract symptoms and quality of life. Clinics. 2011;66(9):1563-8.

34. Marques J, Botelho S, Pereira LC, Lanza AH, Amorim $\mathrm{CF}$, Palma $\mathrm{P}$, et al. Pelvic floor muscle training program increases muscular contractility during first pregnancy and postpartum: electromyographic study. Neurourol Urodyn 2012;32(7):998-1003.

35. Knorst MR, Cavazzotto K, Henrique M, Resende TL. Intervenção fisioterapêutica em mulheres com incontinência urinária associada ao prolapso de órgão pélvico. Braz J Phys Ther. 2012; 16(2):102-7.

36. Knorst MR, Resende TL, Santos TG, Goldim JR. The effect of outpatient physical therapy intervention on pelvic floor muscles in women with urinary incontinence. Braz J Phys Ther. 2013;17(5):442-9.

37. Krüger AP, Luz SCT, Virtuoso JF. Home exercises for pelvic floor in continent women one year after physical therapy treatment for urinary incontinence: an observational study. Braz J Phys Ther. 2011;15(5):351-6.

38. Langoni CS, Knorst MR, Lovatel GA, Leite VO, Resende TL. Incontinência urinária em idosas de Porto Alegre: sua prevalência e sua relação com a função muscular do assoalho pélvico. Fisioter pesqui. 2014;21(1):74-80. 
39. Sousa JG, Ferreira VR, Oliveira RJ, Cestari CE. Avaliação da força muscular do assoalho pélvico em idosas com incontinência urinária. Fisioter Mov. 2011;24(1):39-46.

40. Virtuoso JF, Tonon SC, Krüger AP, Mazo GZ, Birolo NPB, Berreta R. Resultados e adesão do tratamento fisioterapêutico em mulheres incontinentes atendidas na rede pública de saúde. ACM Arq Catarin Med. 2010;39(2):61-7.

41. Araujo MP, Parmigiano TR, Negra LGD, Torelli L, Carvalho CG, Wo L, et al. Avaliação do assoalho pélvico de atletas: existe relação com a incontinência urinária? Rev. bras. med. esporte. 2015;21(6):442-6.

42. Knorst MR, Royer CS, Basso DMS, Russo JS, Guedes RG, Resende TL. Avaliação da qualidade de vida antes e depois de tratamento fisioterapêutico para incontinência urinária. Fisioter. pesqui. 2013;20(3):204-9.

43. Gameiro MO, Sousa VO, Gameiro LF, Muchailh RC, Padovani CR, Amaro JL. Comparison of pelvic floor muscle strength evaluations in nulliparous and primiparous women: a prospective study. Clinics. 2011;66(8):1389-93.

44. Resende APM, Nakamura MU, Ferreira EAG, Petricelli CD, Alexandre SM, Zanetti MRD. Eletromiografia de superfície para avaliação dos músculos do assoalho pélvico feminino: revisão de literatura. Fisioter pesqui. 2011;18(3): 292-7.

45. Alves PGJM, Nunes FR, Guirro ECO. Comparison between two different neuromuscular electrical stimulation protocols for the treatment of female stress urinary incontinence: a randomized controlled trial. Braz J Phys Ther. 2011;15(5):393-8.

46. Gameiro MO, Moreira EC, Ferrari RS, Kawano PR, Padovani CR, Amaro JL. A comparative analisys of pelvic floor muscle strength in women with stress and urge urinary incontinence. Int Braz J Urol. 2012;38(38): 661-6.

47. Riesco MLG, Fernandes-Trevisan K, Leister N, Cruz CS, Caroci AS, Zanetti MRD. Incontinência urinária relacionada à força muscular perineal no primeiro trimestre da gestação: estudo transversal. Rev Esc Enferm. USP. 2014;48(1): 33-9.
48. Massuia FAO, Ladislau CM, Domingues FPA, Gonçalves KLO. Força muscular perineal e respiratória em mulheres Fumantes Dependentes e Não Fumantes: estudo piloto. J Health Sci Inst. 2010;28(3):275-9.

49. Valeton CT, Amaral VF. Evaluation of urinary incontinence in pregnancy and postpartum in Curitiba Mothers Program: a prospective study. International Urogynecology Journal. 2011;22(7):813-8.

50. Rahmani N, Mohseni-Bandpei MA. Application of perineometer in the assessment of pelvic floor muscle strenght and endurance: a reliability study. J Bodyw Mov Ther. 2011;15 (2):209-14.

51. Pereira VS, Hirakawa HS, Oliveira AB, Driusso P. Relationship among vaginal palpation, vaginal squeeze pressure, eletromyographic and ultrasonographic variables of female pelvic floor muscle. Braz J Phys Ther. 2014;18(5): 428-34.

52. Botelho S, Pereira LC, Marques J, Lanza AH, Amorim $\mathrm{CF}$, Palma $\mathrm{P}$, et al. Is there a correlation between electromyography and digital palpation as means of measuring pelvic floor muscle contractility in nulliparus, pregnant and postpartum women? Neurourol Urodyn. 2013;32(5): 420-3.

53. Staskin D, Kelleher C. Patient-Reported Outcome Assessment. In: Abrams P, Cardozo L, Khoury S, Wein A. 5th International Consultation on Incontinence. Paris: ICUD-EAU, 2013. p. 389-427.

54. Fonseca ESM, Camargo ALM, Castro RA, Sartori MGF, Fonseca MCM, Lima GR, et al. Validação do questionário de qualidade de vida (King's Health Questionnaire) em mulheres brasileiras com incontinência urinária. Rev Bras Ginecol Obstet. 2005;27(5): 235-42.

55. Tamanini JTN, Dambros M, D'Ancona CAL, Palma PCR, Rodrigues NJN. Validação para o português do "International Consultation on Incontinence Questionnaire - Short Form” (ICIQ-SF). Rev Saúde Pública. 2004;38(3): 438-44.

Received in 04/05/2016 Recebido em 05/04/2016

Approved in 09/06/2017 Aprovado em 06/09/2017 